\title{
The Three "Thingness Worlds" in the Films of Zhang Yimou - Using Raise the Red Lantern as an Example
}

\author{
Chenlin Wei
}

\begin{abstract}
In the film Raise the Red Lantern, Zhang Yimou utilizes the red lantern as a mysterious symbol, representing identity and status. The lanterns being either lit or extinguished determine the fate of the women in the film's feudal society, showing the helplessness of the female condition. Even those who try to rebel are ultimately powerless against the forces of men; they can only linger sorrowfully under the male oppression. This essay will explore Zhang Yimou's Raise the Red Lantern using Martin Heidegger's theory of the "thingness worlds". Zhang's unique cinematographic perspective and the hidden meaning of the piece will be unveiled by studying the "immediate surrounding world", the "artistic world" and the "future world" in the film.
\end{abstract}

Index Terms-Heidegger, raise the red lantern, world.

\section{INTRODUCTION}

Zhang Yimou's early film Raise the Red Lantern (1991), adapted from Su Tong's novel Wives and Concubines (1990), presents an authentic picture of typical family life in old China. It tells a tragic story about concubines fighting for their husband's favor in the years of the Republic of China (1912-1949), expressing a theme of feudal ethics devouring humanity. The film was made by China Film Co-production Corporation, starring Gong Li, He Saifei, Cao Cuifen, Jin Shuyuan et.al with \$2.6 million, it was the highest-grossing Chinese film in North America at that time. The film won the silver lion prize at the 48th Venice International Film Festival (1991) and was nominated for an Oscar for best foreign-language film. In 2015, it was ranked one of the Top 100 best foreign language movies of all the time by Empire magazine.

As suggested by the title, one of the main visual themes of the film is the red lantern. A good way to decipher its meaning is through Heidegger's theory on the "thingness" world. In the philosophy of Heidegger, the term "things" refers not to physical objects as commonly conceived, but to "the entities as non-Dasein". First discussing the notion of "things", and proceeding to thinking about the essence and meaning of "things", Heidegger examines the very nature of "existence" by inquiring into "the thingly character of the things". The concern with "existence" and "things" makes up a large portion of Heidegger's philosophy.

Despite the popularity of both Raise the Red Lantern and Heidegger, nobody has so far used the theories of the latter to

Manuscript received April 7, 2017; July 25,2017.

Wei Chenlin is with the School of Chinese, The University of Hong Kong, Hong Kong (e-mail: bettywei@hku.hk).

Christian Nordvall is with the School of Chinese, The University of Hong Kong (e-mail: u3003473@connect.hku.hk). analyze the former. This is what we will now attempt to do.

As a successful film, Raise the Red Lantern is different from a so-called "mere thing", which can be seen and touched in daily life; it is rather a "non-thing"1. Because we cannot directly investigate the existence of an artistic work "as a work", we have to begin our analysis from its concrete reality - the "thingly elements" of the work. This article aims to carry out a systematic investigation of the "thingly" features in the film, by use of Heidegger's discussion about "things", analyzing the "three thingness worlds" constructed in this film and the hidden blessing tone submerged in the plot of the film.

\section{The Opening OF "THE SURROUNDING WORLD”}

The backdrop of this film is daily life in feudal society. If we want to understand how this film portrays these daily scenes, especially those which contain distinct features of time and sense of tragedy, we have to pay attention to the objects associated with daily life. Using Heidegger's theory, we can find a way to analyze these daily elements (the "thingly elements" by Heidegger) and their contributions to the film.

In Being and Time, published in 1927, Heidegger classified "things" into "existing things" (there-being), "mere things" and "useful things". His study about the concept of things is mainly concentrated on "useful things", which encounter "there-being" by association. In contrast to "there-being", Heidegger argues that the "useful things" have the characteristic of "handiness", their existence is not alone; "There always belongs to the being of useful things a totality of useful things in which this useful thing can be what it is" [1], which means these useful things can link to others, and join together as a unit. By analyzing "useful things", "handiness", as well as "association", Heidegger unfolded a surrounding world which closely related to daily life.

Heidegger thought that "the thingly element is manifestly the matter of which it consists. Matter is the substrate and field for the artist's formative action.” [2] Zhang makes use of a series of variable "thingly elements" in sketching the outward framework of the film.

The most obvious "thingly element" is the lantern. The lantern in this film is a symbol of identity and status, standing for the favored. When the master chooses which wife to patronize, a lantern will be lit in her yard. Take the fourth wife (and protagonist) Song Lian for example: on their wedding night, lanterns are lit in her yard, Master Chen asks

\footnotetext{
${ }^{1}$ Heidegger considers that the existing things (there-being) and useful things are different from figured things, they can be seen as well as touched, they are used in daily life for working and making contact with. While arts are not limited to practicability, as well as not shown as tangible things.
} 
her to pick up the lantern so that he can see her clearly, and this is the beginning of her gaining grace; but when Song Lian disobeys the master repeatedly, the master shifts his attentions to the other wives, and the yards of the second and third wives are lit. Song Lian then pretends to be pregnant. When the master finds out about the deception he becomes furious and orders to "cover the lanterns". The lanterns being either lit or extinguished signify the fates of the ladies in the Chen family.

The second "thingly element" in the film is the little copper hammer. As a "useful thing”, it's "handiness” is shown when used for foot massage. This is a custom which has almost the same meaning as the lantern lighting. The wife whose lanterns are lit can be served by a specialized handmaiden, because Master Chen thinks that if a woman's feet are comfortable, she is better able to serve her man. However, the original meaning of the ritual is over time lost, so that it is no longer about sensual pleasure, but has itself become a kind of addiction. That is why Song Lian becomes frustrated when hearing the sound of the copper hammer, as if experiencing withdrawal symptoms.

Thirdly, Chinese opera is a constant presence which occurs throughout the film. Some of the most significant scenes featuring this theme are the arias sung by Mei Shan. Its first occurrence is when Master Chen stays with Song Lian. Mei Shan fakes sickness to attract Chen's attention, but fails miserably. She then sings The Red Lady 红娘 which tells the story of the Red Lady taking Zhang Sheng to meet Ying Ying; a story paralleling her own secret affair with her doctor. Its second occurrence is after Chen has had an argument with Song Lian and goes to Mei Shan's place to listen to her sing. Mei Shan sings The Red Lady again along with Su San Qi Jie 苏三起解, in which the phrases 'submitting to humiliation' 忍气吞声 and 'gloomy before speaking'未曾开口心惨淡 are most obviously echoing Song Lian's emotions at that moment. The third occurrence of Chinese opera is during the Mahjong scene. Doctor Gao plays Mei Shan's career-defining piece $Y u$ Bei Ting 御碑亭: Not only is it a subtle indication of the affair between Doctor Gao and Mei Shan, but also a friendly warning from Mei Shan to Song Lian. Its fourth occurrence is when Song Lian fakes pregnancy and unveils Yan'er's secret of privately lighting lanterns in her room, which ultimately leads to Yan'er's punishment and death. Mei Shan sings Peach Blossom Village 桃花村, which includes phrases like 'do not scream and do not shout, you shall observe and you shall listen'. The phrase is evidently a warning to the women of the Chen household. The final occurrence of Chinese opera is upon Mei Shan’s death. Yu Bei Ting 御碑亭 is played again, this time with the lyrics of: "Iffy weather, iffy people; boring days still have a hope. Conspiracies and lost kindness, divorce letter as if a massacre. Hands upon chest and give it a thought, a heartless bastard wang kui is better than you." ${ }^{2}$ This phrase

\footnotetext{
${ }^{2}$ The original text of this paragrah in Chinese opera is: 风雨不测人难 量，阴晴皆有日日光。陈裸袍门良心丧，休书好似杀人场。手摸胸膛 想一想, 负义王魁比你强。
}

is repeated three times in this scene of the film, it can be interpreted as Mei Shan reprimanding Master Chen, it can also be her accusation of the second wife's wrong-doings; moreover, it can be Song Lian's cry for freedom as well as help.

The red lanterns that were supposed to be a light in the darkness and a sign of festivity, instead leads women to their doom like insects to an open flame. The foot massage which was supposed to be a prelude to the excitements of the bed chamber, instead turns into an irresistible drug. The opera which was supposed to be a display of cultural artistry becomes a prelude to death. The dissimilation of these "thingly elements" contributes to the dark and gloomy atmosphere of the film together.

\section{THE DisPersal OF “THE POETIC WORLD”}

In The Origin of the Work of Art published in 1936, Heidegger enlarged the concept of "things", dividing it into "things", "works" and "arts" 3 , questioning the thingly character of the thing by discussing the essence of "works". Compared to mere things and useful things, works not only contain "thingly elements", but also have "other things" "built on top of them", establishing "the world" and "the earth"- this is the artistic expression of Zhang Yimou.

Heidegger believes that "To be a work means to set up a world" 4 [3]. This world is self-created through the work, by which the work can bring us to an independent field totally different from the world in our real daily life. Heidegger's "establish" has two meanings, the first one is "build up", meaning "make space for something", thereby the work can happen in a defined art space. The other one is "open up", "The work holds open the open of the world" ${ }^{5}$ [4]. Heidegger takes Van Gogh's painting A Pair of Peasant Shoes as an example, illustrating the opening of the new world of art --the shoes in Van Gogh's painting are not a "useful thing” any more, they have shed the outward appearance attached to them by the mundane world, now instead representing the happiness of love, the torture of life, the hardship of cultivation, the travail of being, the coming of death ${ }^{6}$ [5]. As a "work", this painting opens up an entirely different new

${ }^{3}$ In The Origin of the Work of Art, Heidegger carried out his discussion from three parts, the first part is "thing and work"; the second part is "the work and truth"; the third part is "the truth and art".

4 "What does the work, as work, set up? Towering up within itself, the work opens up a world and keeps it abidingly in force.”

5 “A work, by being a work, makes space for that spaciousness. 'to make space for' means here especially to liberate the open and to establish it in its structure. This in-stalling occurs through the erecting mentioned earlier. The work sets up a world. The work holds open the open of the world. "

6 "From the dark opening of the worn insides of the shoes the toilsome tread of the worker stares forth. In the stiffly rugged heaviness of the shoes there is the accumulated tenacity of her slow trudge through the far-spreading and ever uniform furrows of the field swept by a raw wind. On the leather lie the dampness and richness of the soil. Under the soles slides the loneliness of the field-path as evening falls. In the shoes vibrates the silent call of the earth, its quiet gift of the ripening grain and its unexplained self-refusal in the fallow desolation of the wintry field. This equipment is pervaded by uncomplaining anxiety as to the certainty of bread, the wordless joy of having once more withstood want, and trembling before the impending childbed and shivering at the surrounding menace of death. This equipment belongs to the earth, and it is protected in the world of the peasant woman. From out of this protected belongings the equipment itself rises to its resting-within-itself." 
world and protects it in the process ${ }^{7}$ [6]; this is the mystery of the "work".

In the film, "the world" refers to the dog-eat-dog world of women. The world cannot tolerate seclusion ${ }^{8}[7]$. Therefore Song Lian leads us along to observe and reveal everything. She is curious about the women's untold fates, and not content to live in a state of complete apathy like the first wife. Song Lian first strives for the master's favor, but when this turns out to be useless, she develops an ambiguous story with her husband's son by another wife (there are only a few scenes between them); the second wife is ambitious and conspiratorial striving for the master's favor; the third wife betrays her husband despite having won favor. Even the first wife, who seems to have a calm disposition, still has a trump card up her sleeve- -her first son. When the young master and Song Lian stand far apart facing each other upstairs, the first wife, the young master's mother, phonates loudly and demands that her son go downstairs. She won't allow any incident, as the existence of her son, the young master, guarantees her an unshakable primary-wife status. But for however colorful the "female world" in the film might be, it cannot help but be constrained by "the male world".

The term "male world" here refers to the agents, traditions and customs by which master Chen and his household subtly control and repress the women, such as the housekeeper, the lantern rituals, Song Lian's stepmother and so on. While not necessarily composed of males only, the "male world" is all the structures which sustain the imbalance of power between the genders. ${ }^{9}$ Now moving on to Heidegger's elucidation of the "earth", we can gain a deeper understanding about the male world in the film.

According to Heidegger, the "earth" refers to "that into which the work sets itself back and which it causes to come forth in this setting back of itself" ${ }^{[8]}$, and "Earth is that which comes forth and shelters. Earth, self-dependent, is effortless and untiring."[8] Heidegger regards the earth in a "work" as silent, secluded, converged: "Earth is that whence the arising brings back and shelters everything that arises without violation. In the things that arise, earth is present as the sheltering agent."[9] But the seclusion of earth is not just "close" _ _ "This setting forth of the earth is achieved by the work as it sets itself into the earth. The self-seclusion of earth, however, is not a uniform, inflexible staying under cover, but unfolds itself in an inexhaustible variety of simple modes and shapes..."[10] In other words, as the shelter of everything, the earth cannot "open up" essentially, therefore it can be self-secluded and remain concealed. Now, it is the work which "lets the earth be an earth"10 [8], [10], exhibiting the

\footnotetext{
7"'This painting spoke. In the vicinity of the work we were suddenly somewhere else than we usually tend to be.”

8“The earth, however, as sheltering and concealing, trends always to draw the world into itself and keep it there."

${ }^{9}$ For instance: when Song Lian steps into the Chen household for the first time, before she has even had time to say her name, the housekeeper stands on a high place while Song Lian stands downstairs, their different positions showing the gap in social status between them; or we might say ,the difference between the Chen household he represents and Song Lian.

10 "The work moves the earth itself into the Open of the word and keeps it there. The work lets the earth be an earth.” "The earth is essentially self-secluding. To set forth the earth means to bring it into the Open as the self-secluding.”
}

seclusion and concealment of earth ${ }^{--}$this is the meaning and value of the work.

In this film, the "earth" is precisely the male word this article mentioned before, referring to the patriarchal society. Specifically, the inescapable Chen household. The various elements of the household manifest a forceful energy, imprisoning everything within its premises. The "earth" per $s e$ is the living quarters of human beings; however, in this film, the earth is also the hiding place for obscuring everything. At the beginning of the movie, we hear an elderly voice, which is full of stress. This is Song Lian's stepmother. Avariciously, she requires Song Lian to follow the women's long-time fate of getting married. However, exactly who her marriage partner is, is never important. In the film, we never see Master Chen's appearance but only hear his voice, or see his figure viewed from behind, his silhouette, or part of his body through a gauze shade. However his hidden face just emphasizes the gloomy and horrible atmosphere of the film. Although he never directly orders to kill anyone, all the death in the film is indirectly caused by him. In addition, the set up of "the earth" has a mantra-like component, namely "custom": the wife who serves can have lights in her room; the wife whose room is lit can give orders; the wife who is pregnant can have ever-burning lights; those who violate the customs shall be put to death, etc. Women's fates are determined by the "custom", which has been passed down for several decades, set by the "male world" for the "female world". All the customs, from outside to inside, from shallower to deeper, layer after layer, forces the "female world" to be held in the "male world". This is precisely what Heidegger meant with the "Earth".

This artistic world, which contains "the world" as well as "the earth", is a world that cannot be "self-clearing" in daily life. Based on this, Heidegger opened up further discussion. Heidegger thought that truth, as unconcealedness, comes from the conflict between world and earth. "One of these ways in which truth happens is the work-being of the work. Setting up a world and setting forth the earth, the work is the fighting of the battle in which the unconcealedness of beings as a whole, or truth, is won." [11] The struggle between "the world" and "the earth", decides the concealing and revelation of the truth; through this "struggle", as well as "unconcealment", the truth can be brought out. While the strife that "is brought into the rift and thus set back into the earth and thus fixed in place is figure, shape, Gestalt."[12] In other words, the crux of arts is truth, lying in the rift, waiting to be brought out.

From this perspective, the world and the earth, as well as the strife between them-taking the form of secrets, here together constitute the film, opening up a new, poetic, artistic world. This is why when we have finished watching the film, we feel an overpowering sense of dread and listlessness: partially due to the blood which colors the lanterns red and the tears shed in the tragedy, but also seemingly something more. We also experience a more profound disturbance. This stems not from the direct action of the plot, but from the general mood of the world the director paints for us. The sense of disturbance derives from the presence of the "thingly elements" described above, but also transcends them. This is how the film goes from being merely a narrative to being 
"art".

Disturbance usually grows out of happiness, anger, sadness or the sum of all fears. All of these words refer to "secrets". This is precisely the "rift"(the contradiction) in this film, which derives from the struggle between "the world" and "the earth". The process of revealing secrets satisfies our curiosity, with indignation generated accordingly, when we feel downcast about the situation, as well as frightened for our unknown future. The entire film is based on this secret, which is also the key to the film, it is the contradiction brought by the strife between "the world" (female world) and "the earth" (male world). The external form of this "rift" is the secret "death house". It is the secret, which is more than reality. It shows the fact that "the female world" is held as well as controlled by "the male world".

When Song Lian asks about "the house of death", the second wife answers her evasively, just saying that women from past generations were hung there, and that it is a taboo subject in the family. When she asks the Master, he replies that "they had been unfaithful". From then on, the audience's passion is ignited, and their curiosity piqued along with Song Lian; the whole film from that point on becomes a process of unraveling the secret. Mei Shan, who is involved in a secret love affair, is ultimately strangled there, which is the first and last time Song Lian directly confronts "the house of death". Song Lian arrives at the house and uncovers the secret there, where the most vivacious life was killed silently. Namely, that under such a cannibalistic social system, the only way out for women (herself included) is to go to "the house of death". Having realized this, Song Lian loses her mind. The following conversation between the Master and Song Lian goes like this: "What did you see?" "You murderers!" "You are mad! You are gone mad!” "Murderers...you murderers!” The audience is sharply hit by the whole meaning of the situation, "the house of death" is the fate of the previous and present women in this family. The first wife is resigned and laconic, a mere symbolic matron of the Chen household; the second wife is an ambitious fighting machine; the third wife is fatally reckless; as for the fourth wife, she ends up a madwoman. All members of the household have been reduced to lifeless puppets, without any of the virtues becoming of their position. Any real life which enters this environment is destined for death. If like Song Lian one is denied a chance to live but also fears the escape of death, only madness remains. The consequence of the struggle between the world and the earth is not countervailing or conglutinating, but the world withheld by the earth.

Therefore, the success of this film results from its exploration of the truth of the work, in other words, its secret. This secret contains not only the fate of Master Chen's women, but also the exposure of the Chinese's private life space. The demonstration of artwork in China is different from that in western society: in the Chinese public space there are tombs underground and screens on the floor, only through these barriers can we glance at their magnificent private life space, and that is the so-called beauty of implicitness in traditional Chinese culture. But Zhang goes the opposite way, he dwells on shooting scenes of the process of massaging feet and lighting lanterns, and also puts things on the screen which are seldom mentioned in traditional
Chinese art, like women's bound feet and the sex life between married couples, which is also showed in his Red Sorghum and Ju Dou. These scenes shock us repeatedly, and through this the secrets of Chinese women are obscurely revealed. Using the framework of the "thingly elements", and the structure of a "male world" and "female world", he builds a surreal artistic world, in which we the audience can take a peep at secrets never told before.

\section{The Possibility of A Future New World}

Nevertheless, Zhang's Raise the Red Lantern is not a mere narration of events. This cinematic masterpiece reaches beyond the plot and introduces visual aesthetic values to the piece through various cinematography techniques. Furthermore, Zhang "gifts" the piece with another thing. "Gift" being a technical term in Heidegger philosophy. The "gift" here is not the one we normally think of in interpersonal communication, but something which cannot be encountered in daily life, it is not present, but comes from another world. It remains the invisible and utterly "concealed" and "hidden" which Heidegger sought in his later period. The "gift" here is not a real object, but a possibility from a future world. It is indecipherable, it is a "nonthing” (non-existing thing), just like Jacques Derrida's "let be", giving out "nothing" means giving out an opening of the new world, providing an unlimitedness and freedom.

A successful piece gives gifts. To what extent does this film adhere to the idea of giving gifts? The sentiment of offering a gift should be blessing, while the fundamental mood of this film is like a curse, imprecating about the secret which restricts women. The author considers that this film gives out a gift-destruction as well as renovation. As the saying goes, "there's no making without breaking", after finding out the secret about women's fate in the Chen family, the audience's nerve is stimulated, reflecting on their own life, a kind of dislodging force generated, which represents the audience's desire to release all of the trapped women. This force is a kind of renovation, exploding the enclosing wall of the Chen family, helping women get rid of the control of the male world and return the original colorful and splendid life back to females.

The accumulation of this strength then comes from a kind of constant action, which refers to a cyclic pattern. In the book One Hundred Years of Solitude, almost all the people of The Buendia Family repeats the same fate, life looks like an endless loop for them. The circulation means stagnation and death. Raise the Red Lantern emphasizes the circulation consciously or unconsciously as well. For instance, the season of spring is not seen in the film. The story begins in summer when Song Lian steps into the Chen household as Chen Zuoqian's fourth wife, the second wife is favored in autumn, while the third wife Mei Shan dies in winter, upon summer next year, the fifth wife is married into the Chen household. Spring is not seen on the screen, just as how spring is not seen in the Chen household. The setting is composed mainly of black bricks and white tiles, along with the ghastly red lanterns. The new wife marries the Master in summer, suggesting the lives of the ladies resemble summer 
flowers, gorgeous yet transient. Towards the end, Zhang utilizes aerial shots, making the boxy compound resemble a coffin. The now insane Song Lian walks round and round in the "coffin", without ever getting out; this is another circulation. Zooming out of the scene, Song Lian's image becomes smaller and smaller, and ultimately fades away at last. This is not the only "coffin" in the world, as Song Lian is not the only woman stuck in this position. The women live the exact same life, following an endless cycle. There are only two ways for a woman to free herself of the Chen patriarchy- the arrogation of Yan'er or the cheating behavior of Mei Shan, yet in the end they both die. When the fifth wife moves in, Zhang takes a close-up shot of her young face, then shoots the foot massage in detail. The old handmaiden describes Song Lian as "the previous fourth wife, she has gone mad". The new wife encounters the one in "the death house”, allowing audiences to experience the smell of death that lingers around the new wife. The old one passed away, the new ones follow the same disastrous path. The scary mood reaches a climax. Together with Song Lian, we realized the fate of her and the common fate of many women of the time. Song Lian keeps her life by losing her mind, but what shall we do? The implied answer is revolution.

The will for change, is the blessing Zhang gifts this film with. Let the rotten roots stay underground, new buds will emerge above. The film gives a seed of the possibility of a new world. Although it is impossible for us to see it grow and blossom, this can be the direction of what we should pursue.

\section{CONCLUSION}

By applying the theories of Heidegger to a subject matter like Raise the Red Lantern, we can raise our understanding of the film from viewing it merely as a snapshot of feudal Chinese society to seeing it as a "work of art" in the Heideggerian sense, and furthermore better appreciate how director Zhang Yimou incorporates the usage of "thingly elements" into his film making style, as well as the "gift" presented: the realization that change requires courage.

By in this way applying western literary theory to an eastern work of art, it is possible to discover previously unnoticed details which may not be readily apparent to the work's original audience. We can thereby see the value of intercultural cross-referencing.

\section{ACKNOWLEDGEMENT}

During the revising process, Mr. Christian Nordvall, who is studying at The University of Hong Kong as a $\mathrm{PhD}$ candidate gives me lots of help in essay polishing. I am impressed by his earnestness in academic study and excelsior attitude, which I need to learn from him without doubt. I really feel grateful to Mr. Christian Nordvall for his help.

\section{REFERENCES}

[1] M. Heidegger, Being and time: A translation of Sein und Zeit; New York: State University of New York, 1996, pp. 64.

[2] M. Heidegger, Poetry, Language, Thought; New York: Harper \& Row, 1971, pp. 26.

[3] M. Heidegger, Poetry, Language, Thought; New York: Harper \& Row, 1971, pp. 43.

[4] M. Heidegger, Poetry, Language, Thought; New York: Harper \& Row, 1971, pp. 44.

[5] M. Heidegger, Poetry, Language, Thought; New York: Harper \& Row, 1971, pp. 33.

[6] M. Heidegger, Poetry, Language, Thought; New York: Harper \& Row, 1971, pp. 35.

[7] M. Heidegger, Poetry, Language, Thought; New York: Harper \& Row, 1971, pp. 47.

[8] M. Heidegger, Poetry, Language, Thought; New York: Harper \& Row, 1971, pp. 45.

[9] M. Heidegger, Poetry, Language, Thought; New York: Harper \& Row, 1971, pp. 41.

[10] M. Heidegger, Poetry, Language, Thought; New York: Harper \& Row, 1971, pp. 46.

[11] M. Heidegger, Poetry, Language, Thought; New York: Harper \& Row, 1971, pp. 54.

[12] M. Heidegger, Poetry, Language, Thought; New York: Harper \& Row, 1971, pp. 62.

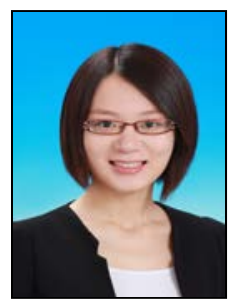

Wei Chenlin was born in China on March 1, 1992, She graduated as a master of arts in 2015 from Renmin University (Beijing, PRC), majored literature \& translation. She also has a bachelor of arts which awarded by Xiamen University (Xiamen, PRC), majored Chinese literature.

She is studying as a $\mathrm{PhD}$ candidate and working as a teaching assistant as well as a research assistant at School of Chinese, The University of Hong Kong (Hong Kong, PRC), and her research interests include film studies, classical novels, cultural exchange between the East and the West.

Miss Wei has got National Scholarship twice in 2013 and 2014 which awarded by Ministry of Education of the People's Republic of China, and has got top students scholarship sextic from 2009 to 2014 which awarded by Xiamen University and Renmin University of China . The following is list of her publications:

[1] Wei Chenlin, 《罗兰巴特理论视域下的福楼拜作品》 on Journal of Northeast Agricultural University (Social Science Edition), vol. 15, no. 1, pp. 58-64, February 2017.

[2] Wei Chenlin, 《密尔的个人与社会自由思想评析》 on Journal of Hebei Normal University (Philosophy and Social sciences Edition), vol. 02, pp. 60-65, March 2015.

[3] Wei Chenlin, 《<紫颜色>的美学意蕴与社会价值一一基于女性主义 视角》 on The world Literature Criticism, vol. 02, pp. 94-99, February 2014.

[4] Wei Chenlin, 《诗情画意——论赵云龙水彩画意境的诗化》on Art research, vol. 04, pp. 1-3, February 2014.

[5] Wei Chenlin, 《例谈莎士比亚戏剧中的暴风雨意象》on Literature Education, vol. 01, pp. 137-139, January 2014.

[6] Wei Chenlin, 《莎士比亚戏剧中的水意象》 on Hebei Academic Journal, vol. 01, pp. 256-258, January 2014.

[7] Wei Chenlin, 《对鲁迅跨世纪与跨文化的审视》 on China Cultural Daily, pp. 2, July 2013.

[8] Wei Chenlin, 《国家社科基金助推文学研究繁荣发展》on Guangming Daily, pp. 3, June 2013.

[9] Wei Chenlin, 《潜心磨著的比较文化新论》 on Comparative Literature in China, vol. 02, pp. 148-150, April 2013.

[10] Wei Chenlin, 《唯美主义理想下的文本一以王尔德童话为例》on Changcheng Journal, vol. 4X, pp. 129-130, April 2013.

[11] Wei Chenlin, 《林徽因与梁思成——纪录片与著作权之比较》 on China Television (TV theory), vol. 04, pp. 43-48, April 2013. 